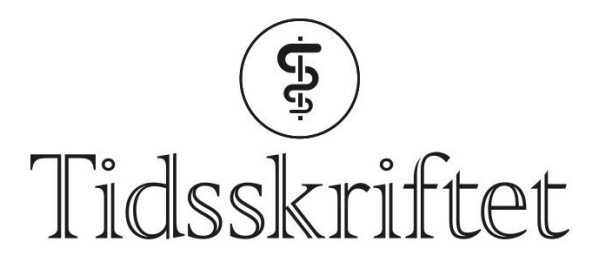

DEN NORSKE LEGEFORENING

\title{
Svekker antipsykotika kognitive funksjoner?
}

FRA ANDRE TIDSSKRIFTER

KETIL SLAGSTAD

Tidsskriftet

Pasienter med psykoselidelser som sluttet med antipsykotiske legemidler, hadde bedre kognitiv funksjon enn de som fortsatte med slik behandling. Dette viser en ny observasjonsstudie.

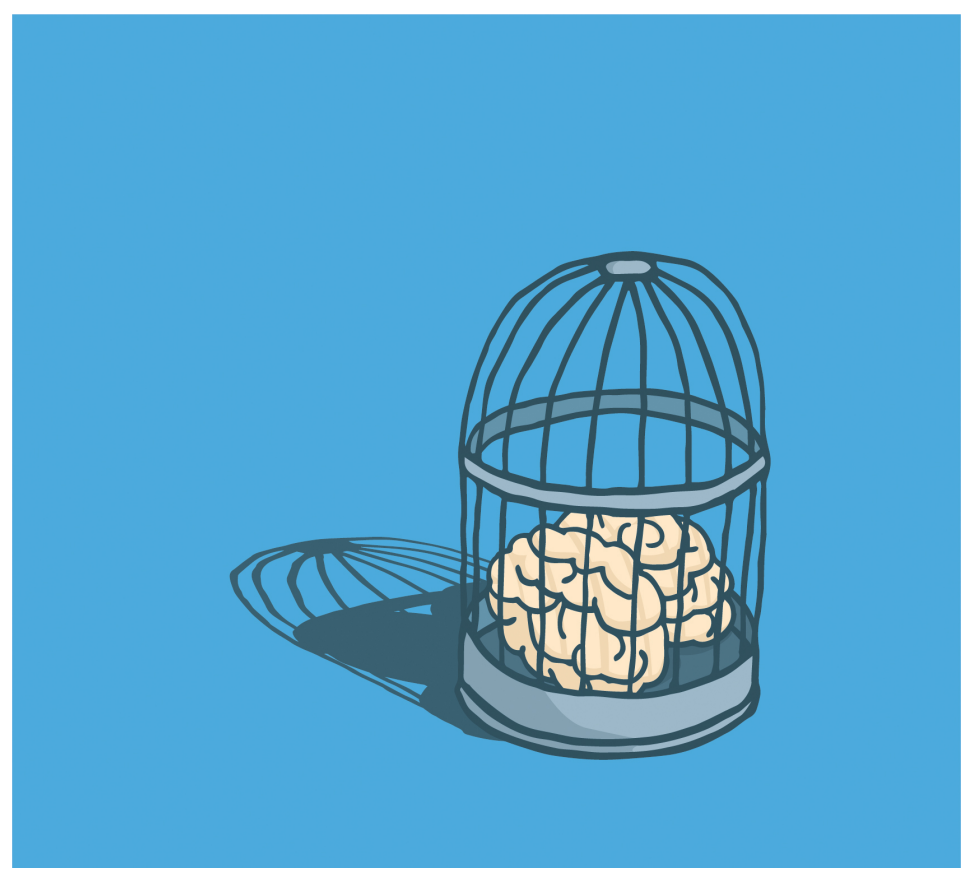

Illustrasjonsfoto: curvabezier/iStock.

Antipsykotiske legemidler er vanligvis en viktig del av førstelinjebehandlingen ved psykoselidelser. Derfor kan det være vanskelig å undersøke naturlig sykdomsforløp og om legemidler virker inn på kognitive funksjoner eller ikke. Studier om dette har vist delvis motstridende resultater.

I en studie som nylig er publisert i tidsskriftet Psychological Medicine, ble 189 danske pasienter med schizofrenispektrumlidelser fulgt over fem år (1). Studien var en forlengelse av en intervensjonsstudie, der førstegangssyke ble randomisert til tidlig

intervensjonsbehandling av ulik varighet. Etter fem år hadde en tredel av pasientene sluttet med medisiner, og denne gruppen skåret høyere på tre ulike tester for kognitive funksjoner 
enn gruppen som fortsatt brukte medisiner. Pasientene som sluttet med medisiner, hadde i utgangspunktet høyere skår på kognitive funksjoner enn de som fortsatte med medisiner. Selv om forfatterne kontrollerte for konfunderende variabler, kan den ikke brukes til å trekke konklusjoner om mulig kausal sammenheng mellom bruk av antipsykotiske legemidler og kognitive funksjoner.

- Dette er en viktig studie, siden den finner en mulig sammenheng mellom det å slutte med antipsykotiske legemidler og bedring av kognitiv funksjon for en gruppe pasienter, sier Kristin Lie Romm, som er psykiater og førsteamanuensis ved Universitetet i Oslo. Kognitiv funksjon har stor betydning for sosialt liv og mulighet for å delta i arbeidslivet. - Det er behov for større randomiserte, kontrollerte studier som kan gi oss sikrere kunnskap om sammenhenger mellom bruk av antipsykotika og kognitiv funksjon, sier Romm, som minner om at pasienter med psykoselidelser er en svært heterogen gruppe med ulike behov og ønsker og at legemiddelbehandling ved psykoser aldri kan være helt standardisert, men må individualiseres og finjusteres.

- Vi vet fra andre studier at i opptil halvparten av tilfellene vil pasienten i perioder slutte helt eller delvis med medisiner - med eller uten legens viten. I den aktuelle studien var det pasientene selv som tok initiativ til å slutte i $95 \%$ av tilfellene, og vi vet vi ikke om legen var informert. Det er legens ansvar å diskutere legemiddelbehandlingen med pasientene og hvorvidt de er fornøyd med denne. Det er viktig at vi som leger møter et ønske fra pasienten om å redusere legemiddeldosen eller seponere legemidlet på en åpen måte, slik at pasientene ikke blir sittende med denne avgjørelsen alene, sier Romm.

\section{LITTERATUR:}

1. Albert N, Randers L, Allott K et al. Cognitive functioning following discontinuation of antipsychotic medication. A naturalistic sub-group analysis from the OPUS II trial. Psychol Med 2018. doi: 10.1017/Soo33291718001836. [PubMed][CrossRef]

Publisert:30. oktober 2018. Tidsskr Nor Legeforen. DOI: 10.4045/tidsskr.18.0659

(C) Tidsskrift for Den norske legeforening 2020. Lastet ned fra tidsskriftet.no 